\section{Передовые статьи}

Шуматов В.Б., Транковская Л.В., Черная И.П., Кузнецов В.В., Королев И.Б., Лебедев С.В.,

Елисеева Е.В., Федоров В.И.

Медицинский университет цифровой эпохи. 5

\section{$0630 \mathrm{pb}$}

Компанеи, Г.Г., Иунихина О.В.

Современные эпидемиологические аспекты геморрагической лихорадки с почечным синдромом: к 85-летию изучения на Дальнем Востоке России ..... 9

Храмова И.А., Черток В.М., Кочьюба А.Е., Черток А.Г.

Структурная организация кровеносной системы матки

\section{Оригинальные исследования}

Фельдблюм И.В., Альева М.Х., Радионова М.В.

Комплексное влияние медико-социальных

и средовых факторов риска на вероятность развития колоректального рака.

Голубкова А.А., Сомова А.В.

Роль Streptococcus pneumoniae в этиологии внебольничных пневмоний в крупном промышленном регионе Российской Федерации

Платонова Т.А., Колтунова Е.С., Голубкова А.А.,

Жиляева И.В., Абдулвалиева В.В.

Практические вопросы вакцинации детей

в условиях поликлиники (по материалам экспертной оценки привитости в индикаторных группах)

Турчанинов Д.В., Стасенко В.Л., Ширлина Н.Г., Щербаков Д.В.

Персонификация оценки индивидуального риска развития колоректального рака у жителей Омской области ......38

Кравченко Н.А., Гаврилова Т.А., Васильева Е.И., Ботвинкин А.Д.

Результаты внедрения системы эпидемиологического мониторинга пневмоний на региональном уровне (по материалам Иркутской области)...

Кузнецова Н.А., Шубин Ф.Н., Раков А.В.,

Яковлев А.А.

Молекулярно-эпидемиологическая оценка влияния процессов глобализации на формирование популяции Salmonella Typhimurium в Приморском крае и других субъектах Сибири и Дальнего Востока.

Бондаренко А.П., Шмыленко В.А., Троченко О.Е.

Эпидемиология назофарингеального носительства пневмококков в семейных очагах

Чемезова Н.Н., Астафьев В.А., Малов С.И., Малов И.В., Кичигина Е.Л., Савилов Е.Д.

Хронический вирусный гепатит C

в Дальневосточном федеральном округе.
Малашенко А.А., Асланов Б.И., Набиева А.С., Эберт М.А., Колосовская Е.Н.

Факторы риска развития инфекций

в области хирургического вмешательства

в детской хирургии

Поздеева Е.С., Омельченко Р.В., Никитина Ю.Н.,

Корнилов М.С.

Влияние распространенности наркомании

среди населения Приморского края на проявления

эпидемического процесса ВИЧ-инфекции.

Нечаев В.В., Иванов А.К., Яковлев А.А., Мусатов В.Б., Федуняк О.И., Васильева М.В., Беляков В.С., Кравцова А.И. Эпидемиология социально-значимых сочетанных инфекций. Факторы риска летальных исходов...

Фомичева Т.Д., Туркутюков В.Б., Сотниченко С.А., Терехов С.М., Скурихина Ю.Е., Окроков М.В.

Микробиологический мониторинг в системе эпидемиологического надзора за гнойно-септическими инфекциями при ожоговой травме.

Герасимов А.Н., Михеева И.В.

Эпидемиологическая ситуация с туберкулезом в России кажущееся благополучие и скрытые угрозы..

Довгополюк Е.С., Левахина Л.И., Тюменцев А.Т.,

Пасечник О.А., Аксютина Л.П.

Характеристика неблагоприятных исходов

ВИЧ-инфекции в Сибирском федеральном округе .79

Кузьменко С.А., Шмакова М.А., Штернис Т.А.,

Сахарова В.М., Брежнева Н.И., Брусина Е.Б.

Закономерности эпидемического процесса инфекций, связанных с оказанием медицинской помощи, вызванных бактериями родов Klebsiella и Acinetobacter у детей..

Корнилов М.С., Яковлев А.А., Поздеева Е.С., Жданова С.Н. Факторы риска, способствующие формированию сочетанных форм туберкулеза и ВИЧ-инфекции в Приморском крае..

Бутакова Л.В., Сапега Е.Ю., Троиенко О.Е., Зайцева Т.А., Каравянская Т.Н., Фунтусова О.А., Ковтонюк Г.П., Феделеш И.Ю., Манджиев Э.Х.

Молекулярно-эпидемиологическая характеристика групповой заболеваемости энтеровирусной инфекцией, обусловленной вирусом Коксаки А6, среди населения Дальнего Востока Российской Федерации в 2016-2017 гг. ..... 92

\section{Организация здравоохранения}

Догадова Л.П., Мельников В.Я., Абдуллин Е.А.

Особенности эпидемиологии глаукомы

в Приморском крае

Титовеи В.В., Можилевская Е.С., Рябченко Л.С., Бъкова Г.А.

Роль детского глазного отделения ККБ № 2

в оказании офтальмологической помощи детям

Приморского края. 


\section{Editorials}

Shumatov V.B., Trankovskaya L.V., Chernaya I.P., Kuznetsov V.V., Korolev I.B., Lebedev S.V., Eliseeva E.V., Fedorov V.I.

Medical University of Digital Era.

\section{Review}

Kompanets G.G., Iunikhina O.V.

Modern epidemiological aspects of hemorrhagic fever with renal syndrome: on the occasion of 85th anniversary of studying in Russian Far East ... 9

Khramova I.A., Chertok V.M., Kotsyuba A.E., Chertok A.G. Structural organization of the uterus circulatory system.

\section{Original Researches}

Feldblyum I.V., Alyeva M.H., Radionova M.V.

Complex impact of medico-social and environmental

risk factors on probability of colorectal cancer development.

Golubkova A.A., Somova A.V.

Role of Streptococcus pneumoniae in the etiology

of community-acquired pneumonia

in a large industrial region of the Russian Federation

Platonova T.A., Koltunova E.S., Golubkova A.A., Zhilyaeva I.V., Abdulvalieva V.V.

Practical issues of vaccination of children in a polyclinic

Turchaninov D. V., Stasenko V.L., Shirlina N.G., Shcherbakov D.V. Personification of evaluation of individual risk of colorectal cancer development in Omsk region residents. .38

Kravchenko O.N., Gavrilova T.A., Vasilyeva E.I., Botvinkin A.D. The results of the implementation of the epidemiological monitoring of pneumonia at the regional level

(based on materials from the Irkutsk region).

Kuznetsova A.A., Shubin F.N., Rakov A.V., Yakovlev A.A. Molecular epidemiological evaluation of the impact of globalization processes on the formation of populations of Salmonella Typhimurium in Primorie and other regions of Siberia and the Far East.

Bondarenko A.P., Shmylenko V.A., Trotsenko O.E.

Epidemiology of of nasopharyngeal carriage of pneumococci in family foci.

Chemezova N.N., Astafiev V.A., Malov S.I., Malov I.V.,

Kichigina E.L., Savilov E.D.

Chronic viral hepatitis $\mathrm{C}$ in the Far Eastern Federal District
Malashenko A.A., Aslanov B.I., Nabieva A.S., Yebert M.A., Kolosovckaya E.N.

Risk factors for surgical site infection in pediatric surgery .61

E.S. Pozdeeva, R.V. Omelchenko, Yu.N. Nikitina, M.S. Kornilov Influence of drug addiction prevalence rate among Primorskiy Territory population on manifestations of the epidemic process of HIV infection.

Nechaev V.V., Ivanov A.K., Yakovlev A.A., Musatov V.B.,

Fedunyak O.I., Vasilieva M.V., Belyakov V.S., Kravtsova A.I. Epidemiology of socially significant co-infections.

Risk factors for deaths

Fomicheva T.D., Turkutyukov V.B., Sotnichenko S.A.,

Terekhov S.M., Skurikhina Yu.E., Okrokov M.V.

Microbiological monitoring in the epidemiological surveillance system for purulent-septic infections in case of burn injury.......... 72

Gerasimov A.N., Mikheeva I.V.

The epidemiological situation with tuberculosis in Russia: an apparent well-being and hidden threats

Dovgopolyuk E.S., Levakhina L.I., Tyumentsev A.T.,

Pasechnik O.A., Aksyutina L.P.

Characteristics of adverse outcomes of HIV-infection

in the Siberian Federal District

Kuzmenko S.A., Shmakova M.A., Shternis T.A., Sakharova V.M., Brezhneva N.I., Brusina E.B.

Epidemiological features of Klebsiella spp. and Acinetobacter spp. infections in the children hospital

Kornilov M.S., Yakovlev A.A., Pozdeeva E.S., Zhdanova S.N. Risk factors that contribute to the formation of combined forms of tuberculosis and HIV infection in Primorsky Krai......... 87

Butakova L.V., Sapega E.Yu., Trotsenko O.E., Zaytseva T.A., Karavyanskaya T.N., Funtusova O.A., Kovtonyuk G.P.,

Fedelesh I.Yu., Mandzhiev E.Kh.

Molecular and epidemiological features of group incidence of enterovirus infection caused by the Coxsackie A6 virus among the population of the Russian Far East in 2016-2017 ....... 92

\section{Public Health Organization}

Dogadova L.P., Melnikov V.Ya., Abdullin E.A.

Epidemiology of glaucoma in Primorskiy territory.

Titovets V.V., Mojilevskaya E.S., Ryabchenko L.S., Bykova G.A. The role of the Children's Eye Department in the provision of ophthalmological care to children of the Primorsky territory...... 99 